\title{
Hacking Muhammad Syahrûr's Hudûd Theory and Its Relevance to the Inheritance of Sangkolan Madurese People
}

\author{
Moh. Mujibur Rohman \\ Pascasarjana Institut Agama Islam Negeri Madura, Jawa Timur, Indonesia, Jl. \\ Raya Panglegur No. Km. 4, Pamekasan, Jawa Timur 69371 \\ E-mail: mujibur.rohman6568@gmail.com \\ Siti Muafatun \\ Pascasarjana Institut Agama Islam Negeri Madura, Jawa Timur, Indonesia, J1. \\ Raya Panglegur No. Km. 4, Pamekasan, Jawa Timur 69371 \\ E-mail: mujibur.rohman6568@gmail.com
}

\begin{abstract}
Muhammad Syahrûr is a modern thinker from Damascus with the theory of hudûd or limits in interpreting the verses of the Qur'an (or al-Tanzil al-Hakîm). One of the theoretical scopes offered is hâlah al-hadd al-adnâ wa al-hadd al-a'lâ mâ'an (minimum and maximum limits simultaneously) which he applies to the inheritance verse. Syahrûr in interpreting the inheritance verse is quite different from classical scholars. He considered classical scholars too rigid in interpreting the inheritance verse. At the same time, for Syahrûr the 2:1 concept would move dynamically according to the hudûd that God had determined in the inheritance verse. The research method used is normative-empirical with a qualitative approach. This study aims to relevance the theory of hudûd Muhammad Syahrûr with the practice of inheritance of the Madurese community in the form of sangkolan. The results of this study indicate that between Syahrûr's hudûd theory, there is relevance to the practice of Sangkolan inheritance of the Madurese community in realizing gender justice either individually (nadzrah al-fardiyah) or collectively based on majmû'at al-dzukûr and majmû'at al-inâts.
\end{abstract}

Keywords: hudûd theory; reconstruction; Sangkolan inheritance; gender. 


\section{INTRODUCTION}

Talking about Islamic inheritance issues will always be cornered with civil matters and gender bias inheritance distribution. The existence of a 2:1 division will always contain an image of inequality and discrimination for the heirs, especially women. This scientific treasure will continue to be dynamic, considering that there is no end to discussing inheritance issues from any point of view. The presence of inheritance or known as ilm al-mîrâts or more commonly as ilm al-farâid is an exciting thing in Islamic studies (Al-Ahdâl). This knowledge has become a scarce thing in today's modern civilization. The need for inheritance or farâid is a necessity, where it is difficult for people who understand and want to apply the concept of inheritance in the text as the basic concept of the Qur'an and the mu'tabar books.

Islam regulates the division of inheritance in the Qur'an and as-Sunnah. This knowledge is so necessary to be studied in depth with the legal status of fardhu kifâyah. Even the Prophet saw. said to Abu Huraira: "O Abu Hurairah! Study ilm al-farâid and teach it, because ilm al-farâid is half of the other sciences, where ilm al-farâid is not easy to remember and is the first science that will be lost from the civilization of my people" (Mâjah). There are two meanings to be addressed in this hadith; First, ilm al-farâid is essential to study because it relates to one's rights (adami rights). So it is essential for the Prophet saw. to state that ilm al-farâid is half of complete knowledge. Second, this knowledge is easy to forget, and one of the sciences was revoked for the first time in the Islamic scientific treasures.

Islamic inheritance civilization is proliferating. This inheritance can not be separated from the issue of justice (gender bias), which always colors in every decade of the development of inheritance itself. Pre-Islamic civilization, the Arab Jahiliyah, divided inheritance based on kinship, pledge of allegiance, adoption ( $\mathrm{al}$ tabanni) (Suryati), and the principle of inheritance like inheritance was influenced by the culture of the Arab community at that time, which was pretty patrilineal. Men must be strong as holders of power to fight in defense of their clan or tribe. At that time, the understanding of the ignorant people was still fanatic towards certain clans or tribes that they adhere. The implication is that women and children are prevented from getting inheritance (Rafiq). Discrimination against women and children in the distribution of jahiliyyah inheritance is clearly illustrated in asbâb al-nuzûl QS. al-Nisa' (4): 11-12.

In the period of ignorance, men are the superpower of family life, the tendency of ignorant people who like to fight and fight to defend the dignity of their tribe or clan. This period requires them (the men) to be stronger and make a prefaith promise that contains a vow to inherit each other if one dies. The purpose of this pre-faith promise is to help and ensure a sense of security for each other (Khisni). The existence of a male figure in a family is essential for the resilience, security, and strength of the family and tribe. This existence requires the ignorant society to do tabanni or adopt a son whose position is like a biological child. The implication is that adopted children can receive an inheritance from those who adopt 


\section{Jurnal Ilmiah Al-Syir'ah Vol. 19, No. 2 (2021): 182-199 \\ Website: http://journal.iain-manado.ac.id/index.php/JIS \\ ISSN 2528-0368 (online) ISSN 1693-4202 (print)}

them (Suryati). This inheritance means that the fanaticism of power (tribes) and the state of the ignorant Arab society who liked to move around (nomadic) influenced the inheritance system at that time.

Post-Jahiliyah, Islam, the religion of rahmah li al-'alamin comes with a new civilization and order in inheritance. Islam, with one of its principles, is gradually enforcing Shari'ah (Al-Shâbûnî). At first, the inheritance system during the jahiliyyah period did not experience significant changes. It's just that there are other principles for the smooth purpose of da'wah. This addition seems to allow inheritance between the Muhajirin and the Ansor within the framework of brothers or known as al-muakhah (Khisni). This group aimed to build trust in Islam with adherents who were still a minority at that time and instill a good image of the close bond of brotherhood among Muslims (Rafiq).

It did not last long, the principle of jahiliyyah inheritance was refuted by the revelation of the verse of the Qur'an surah an-Nisa' (4): 7, which states that men and women, be they, children or adults, still get a share of the inheritance according to the provisions. What happens in the Qur'an. Islam has begun to erode inheritance practices that discriminate against women and children. Likewise, there is tabanni (adoption of children) which was also erased based on the Qur'an surah al-Ahzab '(33): 4-5. Not only that, the condition of the Muhajirin and Ansor cannot inherit from each other. This change is based on the command of Allah Swt. in QS. alAhzab '(33): 6, who is more concerned with the rights of incest. The rules of inheritance are also increasingly complex with the divisions contained in the Qur'an as in Surah an-Nisa' (4): 11-13. The argument qath'î (patent) regarding inheritance in the Qur'an confirms a 2:1 difference between male and female shares.

At the time of the Prophet Muhammad saw., an activist in inheritance and quite proficient was Zaid bin Thabit (Al-Hadhramî). The latter was the secretary of the Prophet Muhammad as a recorder of revelation when it came down (AlShâbûnî). Islamic inheritance civilization as an independent science (ilm al-farâid) continues to grow more complex. It becomes a challenging and warm discussion when gender justice becomes the main topic of discussion. The 2:1 division, where men benefit from a smaller share of women, is a separate problem and still discriminatory against women. The emergence of thinkers and experts to change the inequality of gender justice in Islamic inheritance law. One of them comes from contemporary thinkers from the land of Damascus, Syria. Namely, Muhammad Syahrûr Ibn Dayb was classified as a liberal thinker.

The author admits that the study of Muhammad Syahrûr's thoughts with the theory of hudûd is not new. Many previous researchers, such as "The Inheritance of Gender Equality: A Comparison of Perspectives of Wahbah al-Zuhaily and Muhammad Syahrur," compare two contemporary thinkers from Damascus with different scientific backgrounds (Yudha). Next, the title "Gender Justice in the Law of Islamic Inheritance Distribution Perspective The Theory Of Limit Muhammad Syahrur." This article examines gender justice in the limit theory developed by Muhammad Syahrûr Ibn Dayb (Murtadlo). Next, Mustaqim's work is entitled " 
hudûd Muhammad Syahrur's Theory and Its Contribution to the Interpretation of the Qur'an." This article examines the hermeneutic interpretation of Muhammad Syahrûr in contributing to the treasures of the science of interpreting the Qur'an. Syahrûr hudûd theory tried to give a new nuance in interpreting the Koran by interconnecting the science of interpretation, modern linguistics, and modern science, especially the exact sciences (Mustaqim). Likewise, with traditional inheritance in the form of Sangkolan, which also includes research such as Maimun's work entitled "The Existence of Mèkol Nyo'on Formula in Traditional of Inheritance Division in Madura," which examines the 2:1 concept in human life known as mun lake' mekol mun bine'nyu'on. That is, the burden of men is more significant than women (Maimun).

So the research that the author is doing is the development of several previous studies to study the theory of hudûd theory Muhammad Syahrûr and its relevance to the Madurese traditional inheritance system in the form of Sangkolan. Novelty in this study is the relevance of Syahrûr's limit theory to the Madurese inheritance system in the form of hibbe inheritance in the form of Sangkolan and its manifestation in realizing gender justice. This distinguishes it from previous research, and there is no previous study examining these two inheritance systems simultaneously. The focus of the research that the author wants to find is: First, how is the reconstruction of Muhammad Syahrûr through the theory of hudûd theory and gender justice that he built in Islamic inheritance?: second, how is the system of division of traditional Madurese inheritance known as Sangkolan?: third, how is the relevance between the concept of justice Muhammad Syahrûr through the hudûd theory with the traditional inheritance of the Madurese community?

\section{RESEARCH METHODS}

The most crucial thing in a study is the approach, type of research, and data analysis techniques. The research conducted by the author is normative-empirical research with a qualitative approach. It is normative because this research will examine the concept of thought and theory of hudûd theory initiated by Muhammad Syahrûr, of course with various existing literature. In addition, this study includes inheritance practices in a place, namely Madura, to understand the empirical (field) step. The data obtained is analyzed using an induction technique that begins with a theoretical study of facts, then looks at reality relevant to society. Then, between facts and reality, it will form a general pattern (Raco).

\section{RESULTS AND DISCUSSION}

\section{Knowing Muhammad Syahrûr's Way of Thought and the Birth of the Hudîd (Limit) Theory}

Muhammad Syahrûr Ibn Dayb (from now on referred to as Syahrûr) is a contemporary thinker from Damascus, Syria, classified as a liberal thinker. Born March 11, 1918 AD, he is the fifth child of a mother named Siddiqah bint Salih Filyun with Deyb Ibn Deyb Syahrûr, who works as a dyer. Syahrûr himself is 


\section{Jurnal Ilmiah Al-Syir'ah Vol. 19, No. 2 (2021): 182-199 \\ Website: http://journal.iain-manado.ac.id/index.php/JIS ISSN 2528-0368 (online) ISSN 1693-4202 (print)}

married to Azizah; from this marriage, he was blessed with five children named Tariq (who has wife Rihab), al-Laits (has wife Olga), Rima (has husband Luis), Basil, and Masum (Ismail).

Little Syahrûr's scientific odyssey began in his homeland, Syria. He took from primary to secondary education at the educational institution Abdur Rahman al-Kawakibi, graduating in 1957 AD (http://www.shahrour.org). In 1964 AD, young Syahrûr continued to study civil engineering (Hadassah al-madaniyah) in Saratow, Soviet Union (now Russia), on a scholarship from the Syrian government. He met Ja'far Dek al-Bab, a shâhib as well as a teacher in terms of grammar or linguistics, who became the forerunner of his thinking (Muamar). During his stay in Russia, Syahrûr's thoughts began to be influenced by the direction of Marxism. Although he denies this, many of his religious works adhere to the Marxist theory (Yudha). In 1968-1972 AD, Syahrûr again received a scholarship for an MA (as a Master's degree) and a Ph.D. (as a Doctoral degree) in Soil Mechanics and Foundation Engineering. Syahrûr's name came to the fore and was known in the academic world since he was appointed as Professor of Civil Engineering at Damascus. In addition, he has also started to pioneer a small company in the field of engineering with privately-owned status (Syahrur).

Based on the traces of education that Syahrûr took, he did not receive the discipline of Islamic education. However, the engineering background did not dampen his enthusiasm for studying Islamic themes. It is proven that his work has many Islamic titles; (1) al-Kitâb wa al-Qur'ân; Qirâ'ah Mu'âshirah, this book is the most phenomenal work in discussing the theory of hudûd theory (limit or limit). Cultivation of this book began when Syahrûr took master's and doctoral studies at the National University of Ireland, Dublin. With Ja'far Dek al-Bab. First printed in 1990 and until now has reached its tenth printing; (2) Dirâsât Islamiyyah Mu'âshirah fî al-Daulah wa al-Mujtama' (1994); (3) al-Islam wa al-Îman: Mandzumah al-Qiyam (1996); (4) Nahwa Ushul Jadidah li al-Fiqh al-Islâmi: Fiqh al-Mar'ah (2000), this book is then known as its translation in Indonesia "Contemporary Islamic Fiqh Methodology." These four books were published through the same publisher, al-Ahâli, a left-wing publisher with liberalist works (Syahrur, 2015, see also http://shahrour.org).

Syahrûr's passion in studying Islamic themes is an effort to construct the thoughts of classical scholars. According to Syahrûr, the massive public understanding of the interpretation products of classical scholars causes infertility in judging contemporary religious issues (Murtadlo). For him, the Qur'an (from now on referred to as al-Tanzîl al-Hakîm) cannot be understood as a revelation that only came down at the time of the Prophet Muhammad, who took place in Arabia. But al-Tanzîl al-Hakîm also corresponds to places other than Arabia and for the times after the Prophet (shâlih li kull zamân wa makân). This understanding became known as the legal universalism of al-Tanzîl al-Hakîm. He also thinks that asSunnah -the hadith of the Prophet saw.- is not a second revelation but only limited to the initial understanding of al-Tanzîl al-Hakîm. The Messenger of Allah was the first mujtahid to ground (relative) the laws of Allah. Based on this universalism 


\section{Jurnal Ilmiah Al-Syir'ah Vol. 19, No. 2 (2021): 182-199 \\ Website: http://journal.iain-manado.ac.id/index.php/JIS ISSN 2528-0368 (online) ISSN 1693-4202 (print)}

thought, Syahrûr believes that al-Tanzîl al-Hakîm is a field for conducting Ijtihad that is adapted to objective conditions or conditions in the human community (Syahrur).

Syahrûr's understanding of the verse of al-Tanzîl al-Hakîm used the linguistic theory as he learned from his shâhib named Ja'far Dek al-Bab. There are at least two cores of Syahrûr's linguistic understanding, namely, 1) there is a significant correlation between language and thought; 2) rejecting murâdif (synonymity) (Saifuddin). As a result, he redefined between words that have synonyms in the eyes of others. Such as the use of the words "al-Qur'ân," "al-Kitâb" and "al-Dhikr." Syahrûr's version of the meaning of al-Kitâb is a general term (generic term) that includes all written texts (mushaf). At the same time, the partial form of the content of al-Kitâb is called al-Qur'ân. Meanwhile, al-Dhikr is understood as a phenolic form of things that are spoken from al-Kitâb (Syahrur).

An example of a linguistic approach that can be applied to life is the difference between Qur'an and recitations. Syahrûr considered that many misconceptions when someone reads the Qur'an in an event or celebration they call it qira'ah al-Qur'an. Whereas definitively, qira'ah is the reading of the Qur'an accompanied by an explanation of the content of the verses read, such as the study of the Qur'an, it can be called qira'ah al-Qur'an. Unlike the case with recitations which only recite the text of the Qur'an in a melodious voice (Syahrûr).

The continuous use of linguistic theory is combined with Syahrûr's educational background in the exact sciences. Led Syahrûr to conduct an Islamic study with his scientific understanding, thus giving birth to "the theory of limit," known as the hudûd theory (limit). This theory is an original contribution theory from 1970-1990 (Mustaqim). The naming of the hudd (boundary) theory itself

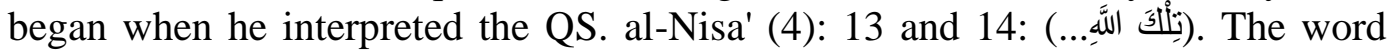
"hudûd" is the plural form of the word "hadda" (حد) with the meaning as a barrier between two things (al-hâjiz baina syaiaini). At the same time, in the linguistic order or manthiqi it is defined as the essence of a word (Anis). In Islamic studies, like the science of fiqh, the term "hudûd" is often found with the meaning of punishment (al-uqûbah).

Broadly speaking, "the theory of hudûd theory " Muhammad Syahrûr is classified into two parts. First, al-hudûd fi al-Ibâdah, a ritual of worship whose provisions have been patented since the time of the Prophet saw. until now (does not require Ijtihad). The two, al-hudûd fi al-tasyri' which he divides into six typologies (Syahrur): These six typologies are 1) hâlah al-hadd al-adnâ (minimum limit) ijtihad on marrying cousins (QS. al-Nisâ '(4):13); 2) hâlah al-hadd al-a'lâ (maximum limit) discussing the matter of cutting hands for thieves (Surah AlMaidah (5): 38); 3) hâlah al-hadd al-adnâ wa al-hadd al-a'lâ mâ'an (minimum and maximum limits at the same time) reviewing inheritance verses (Surah al-Nisâ' (4): 11-13.); 4) hâlah al-hadd al-adnâ wa al-hadd al-a'lâ mâ'an alâ nuqthatin wâhidah (minimum and maximum limits in one coordinate) regarding the punishment of stoning for adulterers (Surah Al-Nûr (24): 2 ); 5) hâlah al-hadd al-a'lâ bi khathtin 
muqâribin li mustaqîmin wa lâ yamsi (maximum limit approaching a straight line but not touching) examines the prohibition of approaching adultery (muqaddimah al-zinâ) (Surat al-Isrâ' (17): 32); 6) the maximum limit is positive while the minimum limit is negative with a study of usury as the maximum limit and zakat as the minimum limit.

To deepen the understanding of the six typologies of al-hudûd fi al-tasyri', a mathematical method (al-riyâdhiyât) is needed. This mathematical approach is a breakthrough from Syahrûr so that efforts to relativize the Qur'an with modern science will be realized, and the Qur'an is no longer seen as rigid like the work of classical scholars. The mathematical approach used is Issac Newton's theory of functional equations with the formula $Y=f(x)$, which is used when one variable and the formula $\mathrm{Y}=\mathrm{f}(\mathrm{x}, \mathrm{z})$ is used if there are two or more variables (Syahrûr). See the following image:

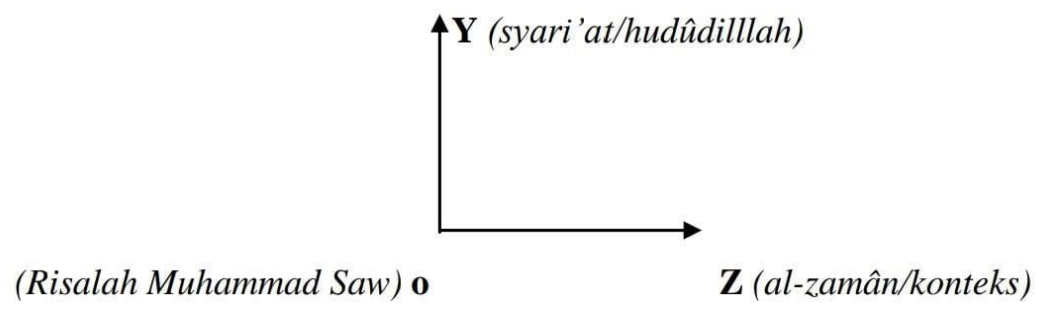

Figure 1. Mathematical Method (al-riyâdhiyât)

Source: Muhammad Syahrû dalam al-Kitâb wa al-Qur'ân; Qirâ'ah Mu'âshirah

As Syahrûr in relativizing al-Tanzîl al-Hakîm, the symbol Y is the limit (alhudûd) that Allah Swt. has set. In contrast, the symbol o is the beginning of the message since the Prophet (beginning of Ijtihad). The symbol X is the circulation of time or era that characterizes Ijtihad. The circulation of Ijtihad continues to move along the $\mathrm{X}$-axis but remains within the limits of the $\mathrm{Y}$-axis (Syahrûr). Syahrûr's mathematical approach colors every typology of hudûd theory offered, including inheritance.

\section{Verse of Inheritance and Reconstruction of Muhammad Syahrûr}

Studying inheritance means studying wills because both are the most meaningful things in the treasures of Islamic scholarship. For him (Shahrûr), there are four unsolved contemporary reasons why inheritance and will are considered essential and included in the main discussion. First, inheritance is part of al-Tanzîl al-Hakîm. Second, the concept of will and inheritance becomes passive and massive knowledge through the understanding of previous fiqh (fuqahâ') experts. Third, the existence of community confinement in understanding two concepts (will and inheritance) based on farâ'id books and Ilm Irtsi. Fourth, there is a socio-cultural community through customary inheritance that is used in Arab and non-Arab countries (of course not according to the Qur'an and inheritance books) (Syahrur).

Hacking Muhammad Syahrûr's Hudûd Theory And Its Relevance To The Inheritance Of Sangkolan Madurese People 


\section{Jurnal Ilmiah Al-Syir'ah Vol. 19, No. 2 (2021): 182-199 \\ Website: http://journal.iain-manado.ac.id/index.php/JIS ISSN 2528-0368 (online) ISSN 1693-4202 (print)}

Syahrûr tried to reconstruct the verses of inheritance and wills. Syahrûr regretted the understanding of classical scholars who were so rigid and forced too much understanding of the verses of will and inheritance. Syahrûr's reconstruction is recorded in the analysis of the verses of will and inheritance, namely: First,

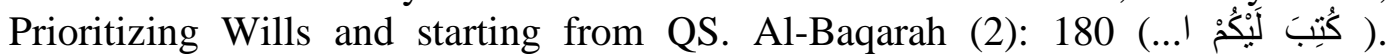
According to Syahrûr, the verse shows the command (AMR) as Allah has made it mandatory (taklîf) prayer and fasting. Syahrûr evidences this that the inheritance verse above in al-Tanzîl al-Hakîm begins with the word "kutiba 'alaikum" (كُتَبَ لََُْْْم) which is in line with the fasting command لَيْكُمُ الصِيَّامَ in QS. Al-Baqarah (2): 183. So a will is a command from God that is imposed on all humankind (as mahallu alwashiyyah) whose target is regardless of gender position (universal) and is covered for all family groups (al-aqrabîn) in general (Syahrur).

Second, there is no text of wills. The most crucial construction carried out by Syahrûr was to reject the methodology of understanding the classical scholars who omitted wills under the pretext of nasakh. For him, the abolition of this verse law is a socio-political agenda to hegemony and intervene in the pace of development of fiqh, which tends to be ahistorical (Syahrur). In the plains of classical scholars' opinion, the testamentary verse is confirmed by the hadith of the Prophet narrated by al-Maghâzî which reads: لا لوارث (the will is not intended for heirs). This means that the ulama did not abolish the will in its entirety, only limiting the distribution of wills intended for other than heirs and should not exceed 1/3 (AlMalībāri). Overall, Syahrûr rejects the concept of nasakh on al-Tanzîl al-Hakîm (Syahrur). As the initial understanding that the Prophet's hadith is the result of the Prophet's Ijtihad in relativizing the Qur'an, it means that Syahrûr does not accept if the text is applied to al-Tanzîl al-Hakîm through the Prophet's hadith.

Third, the Fatality of Verse Interpretation and Improper Use of Word Diction. There is a wrong word diction from the understanding of classical scholars; they consider the same as "nashîb" (نَصِيُّ) and "hazh" (حَظِ) Linguistically for Syahrûr the word "nashîb" connotes a will as pronounced in the QS. al-Nisâ' (4): 7 (للِرِّجَالِ مِمَّا...), while the word "hazh" connotes inheritance contained in the QS. al-

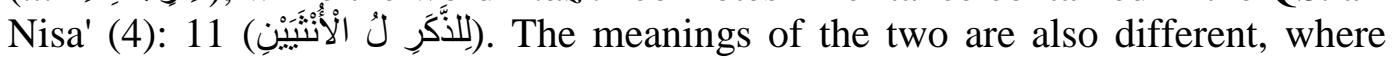
"nashîb" implies the meaning as a portion, while the word "hazh" implies the share of the inheritance (Syahrur). In addition, there is still a linguistic approach to some of the lafaz contained in the inheritance and testament verses which are considered to be understood with wrong diction by classical scholars, like the pronunciation of "al-awlâd" (أو لاد). For him, the word "al-awlâd" is a plural form (jama') of the word "walad" which includes both masculine (male) and feminine (daughter) meanings; this means that the target is intended for the general population of the earth and every human being born (Syahrur).

Syahrûr (2015) criticized classical scholars who read "li adz-dzakari mitslu haddzi al-untsayaini" (meaning: for a man, such as the part of two girls). But with the application of reading "li adz-dzakari mitslâ haddzi al- untsayaini" (meaning: for a boy, it is equal to twice the share of a girl). For him, the word mitslu has three variables; (1) Followers (tabi') are men (symbol Y); (2) The changer (mutahawwil)

Hacking Muhammad Syahrûr's Hudûd Theory And Its Relevance To The Inheritance Of Sangkolan Madurese People Moh. Mujibur Rohman, Siti Muafatun 


\section{Jurnal Ilmiah Al-Syir'ah Vol. 19, No. 2 (2021): 182-199 \\ Website: http://journal.iain-manado.ac.id/index.php/JIS ISSN 2528-0368 (online) ISSN 1693-4202 (print)}

is a woman (symbol $\mathrm{x}$ ); and (3) specific variable (mutahawwil mafrûd) namely the number of women who sometimes switch from one, two, three and more. Illustrated by the formula for the equation of the function $Y=f(x)$. Because the male $(Y)$ in the inheritance verse is mentioned once, so the $\mathrm{Y}$ (male/follower) share will change with the value of $\mathrm{x}$ (female/variable).

Fourth, About Justice. Understanding (Syahrur) the verse 'am does not mean a special nasakh. The application of universal justice (in the inheritance verse) and specific justice (in the will verse).

Fifth, reject the concept of al-'Awl (العول) and al-Radd (الرد). The classical inheritance concept recognizes the names al-'awl (العول) and al-radd (الرد). al-'Awl in language review (lughat) rises or is high (al-raf'u) (Al-Nawâwî). At the same time, the term review is the occurrence of the addition of the Siham while the heirs reduce (Al-Zuhailî). 'Aul was first initiated by the caliph Umar al-Khattab (AlAhdâl). The meaning of al-radd (الرد) is al-'audu wa al-rujû' which means "return." The definition of the term revealed by the jurists of fiqh radd is to return the remaining part of the $d z \hat{a} w i l$ furûdh according to the size of their share because there are no other recipients (Wahidah). Syahrûr considers the concept of inheritance division in the form of $a l$-'awl and al-radd to injure the distribution of inheritance so that the recipient of the inheritance receives excessive property. At the same time, the other party is unfairly reduced in his share (Syahrur).

Sixth, there is a replacement heir. Syahrûr imposed a replacement heir. A grandson whose parents have left him is still entitled to an inheritance from a grandfather as a substitute for his deceased parents (Syahrur).

Seventh, Refuse the Addition of Heirs. Strongly disagree with the acceptance of inheritance from those who are not stated in the inheritance verses. Like, uncle (from the father's side / ع ) and so on. Syahrûr accused the existence of practical social and political reasoning in the classical period that injured the distribution of inheritance so that he ran away from the actual provisions of the Qur'an (Syahrur)

After conducting a long study, Syahrûr finally determined that the will is more dominantly mentioned in the Qur'an than the inheritance verse. This is a reference that the will is superior or prioritized over the division of inheritance. Verses of wills are recorded ten times in the Qur'an, including QS. Al-Baqarah (2): 180. While the inheritance verse is said to be more or less, there are only three

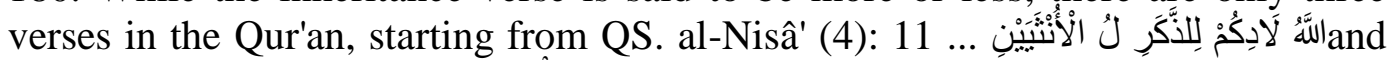

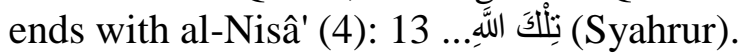




\section{Minimum and Maximum Limit Theory (2:1) in Realizing Gender Equity}

As explained earlier, that al-hudûdfi al-tasyri'-field of ijtihad theory of hudd Syahrûr- has six typologies, one of which is hâlah al-hadd al-adnâ wa al-hadd ala'lâ mâ'an (minimum and maximum simultaneously) with the application of the study on the inheritance paragraph. The concept of inheritance in the Qur'an implies a two-to-one division (2:1). Divided (Syahrur) shows the maximum and minimum division in inheritance. The share of inheritance cannot exceed number $2(66.6 \%$ of the total assets) for men as the maximum limit, while the minimum limit for women's shares is not less than number 1 (33.3\% of total assets). In understanding the share of men is equal to the share of two women, the cycle of inheritance distribution moves statically based on the number of female inheritors as a variable (mutahawwil). In more detail, Syahrûr describes the inheritance verse curve based on the limit theory, as follows (Syahrûr).

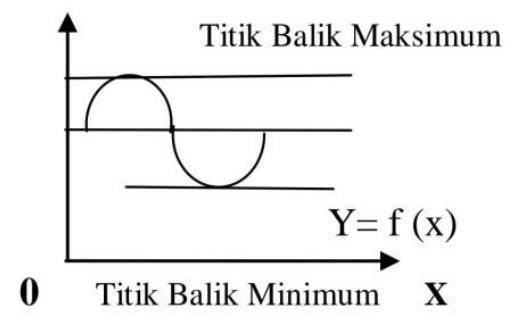

Figure 2. Minimum and Maximum Limit Theory (hâlah al-hadd al-adnâ wa al-hadd al-a'lâ mâ'an)

Source: Muhammad Syahrû dalam al-Kitâb wa al-Qur'ân; Qirâ'ah Mu’âshira

The concept of inheritance distribution based on the theory of maximum and minimum limits is divided into three parts concerning the sound of the inheritance verse stipulated by Syahrûr, namely: First, the male share is twice the female share (2:1). The share of men in getting the inheritance is twice the share of women (2:1). This concept tends towards the sound of the verse "li adz-dzakari mitslu haddzi al-untsayaini". Portion 2:1 occurs when the number of female heirs is a multiple of the number of male heirs. For example, in a family, there is one man and two women or two men and four women and so on (Syahrur). As one example, a person dies, leaving an heir of a son and two daughters. The applicable law is that the boy gets $50 \%$, and the remaining $50 \%$ is divided between two girls (each girl gets a $50 \%$ share: $2=25 \%$ ). 


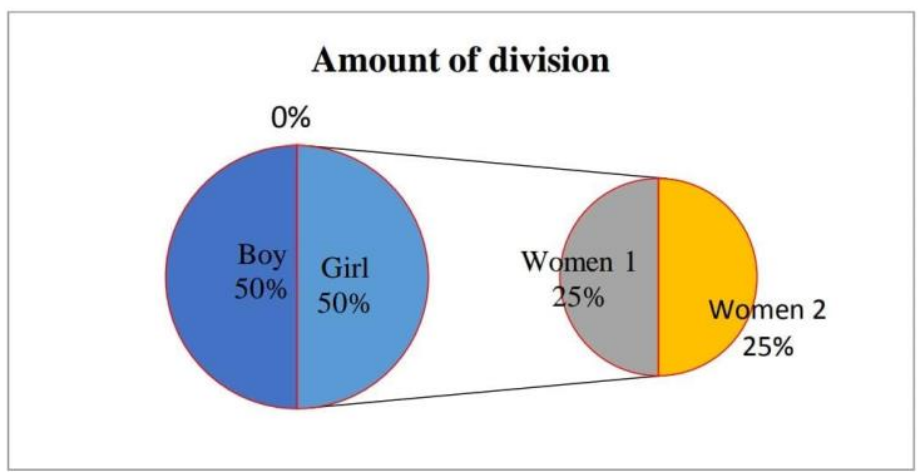

Figure 3. Amount of Division

Source: The author's interpretation in giving an overview to make it easier

Table 1. Division Rule

\begin{tabular}{ccc}
\hline $\begin{array}{c}\text { Number of } \\
\text { Inheritors }\end{array}$ & $\begin{array}{c}\text { Ration Male } \\
(\mathbf{M})\end{array}$ & Ration Women $(\mathbf{F})$ \\
\hline $1(\mathrm{M})+2(\mathrm{~F})$ & $\begin{array}{c}1 / 2 \text { divided by } \\
\text { one } \mathrm{M}\end{array}$ & $1 / 2$ divided by two $\mathrm{F}$ \\
$2(\mathrm{M})+4(\mathrm{~F})$ & $\begin{array}{c}1 / 2 \text { divided by } \\
\text { two } \mathrm{M}\end{array}$ & $1 / 2$ divided by four $\mathrm{F}$ \\
$3(\mathrm{M})+6(\mathrm{~F})$ & $\begin{array}{c}1 / 2 \text { divided by } \\
\text { three } \mathrm{M}\end{array}$ & $1 / 2$ divided by six $\mathrm{F}$ \\
& & \\
\hline
\end{tabular}

Source: Muhammad Syahrû in Contemporary Islamic Fiqh Methodology

Second, Men Get 1/3 (33.3\% of Total Assets), and Women Get 2/3 (66.6\% of Total Assets). This limitation applies when the number of women is more than twice the number of men. The share received by women is $2 / 3$, while the male group gets $1 / 2$ of the total assets. This is based on the verse "fa in kunna nisâ'an fauqa itsnatayni falahunna tsulusa ma tarak" (Syahrur).

Table 2. Distribution Rules

\begin{tabular}{ccc}
\hline $\begin{array}{c}\text { Number of } \\
\text { Inheritors }\end{array}$ & Ration Male $(\mathbf{M})$ & $\begin{array}{c}\text { Ration Women } \\
(\mathbf{F})\end{array}$ \\
\hline $2(\mathrm{M})+5(\mathrm{~F})$ & $1 / 3$ for two person & $2 / 3$ for five person \\
$1(\mathrm{M})+7(\mathrm{~F})$ & $1 / 3$ for one person & $\begin{array}{c}2 / 3 \text { for seven } \\
\text { person }\end{array}$ \\
\hline
\end{tabular}

Source: Muhammad Syahrû in Contemporary Islamic Fiqh Methodology

As an example, there are heirs with the details of 2 men and five women. Then the male group gets $1 / 3$ share $(33.3 \%)$ so that each gets $33.3 \%: 2=16.65 \%$. While the share for women is $2 / 3$ share $(66.6 \%)$, if broken down, each gets $66.6 \%$ : $5=13.32 \%$. 


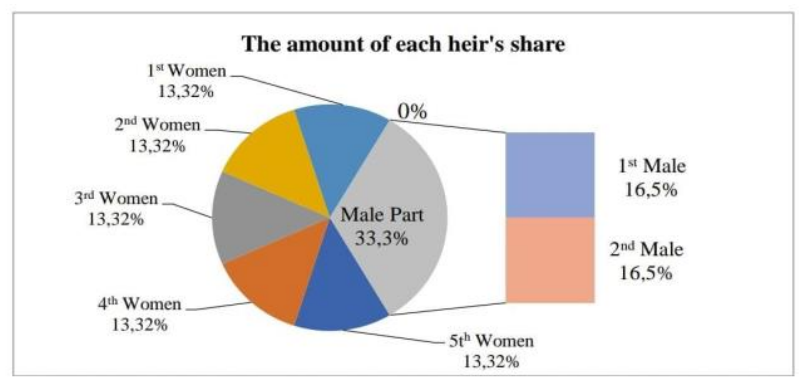

Figure 4. The amount of each heir's share

Source: The author's interpretation in giving an overview to make it easier

Third, Women Get 1/2 (50\% of Total Assets). The following limitation is when the heir is a woman alone; she gets a share of $1 / 2(50 \%$ of the total inheritance). Even if the heirs between men and women are equal, this rule also applies (50\% for men and 50\% for women), based on the verse "wa in kânât wahidatan fa lahâ al-nishf."

Table 3. Ration of Inheritors

\begin{tabular}{|c|c|c|}
\hline $\begin{array}{l}\text { Number of } \\
\text { Inheritors }\end{array}$ & Ration Male (M) & Ration Women (F) \\
\hline $1(\mathrm{M})+1(\mathrm{~F})$ & $1 / 2$ for one person & $1 / 2$ for one person \\
\hline $2(\mathrm{M})+2(\mathrm{~F})$ & $1 / 2$ for two person & $\begin{array}{l}1 / 2 \text { for two person } \\
\text { (@ 1/4) }\end{array}$ \\
\hline $3(\mathrm{M})+3(\mathrm{~F})$ & $\begin{array}{l}1 / 2 \text { for three } \\
\text { person }\end{array}$ & $\begin{array}{c}1 / 2 \text { for three person } \\
(@ 1 / 6)\end{array}$ \\
\hline
\end{tabular}

For example, there are heirs left in the form of three women and three men in a family. The number of the two groups of heirs is equal, so use this rule as described in the table above. This methodology means that if the share of three women is broken down, it is $1 / 2$ (or $50 \%: 3$ women $=16.6 \%$ ), as well as the share of three men by taking the remaining $50 \%$, then divided by three by the same unit, namely $16.6 \%$. So from the six heirs, each gets $16.6 \%$.

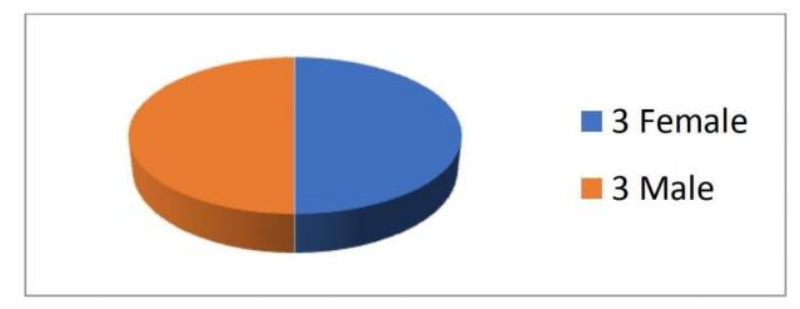

Figure 5. The Portion of the Division in the Third Rule

Source: The author's interpretation in giving an overview to make it easier 


\section{Jurnal Ilmiah Al-Syir'ah Vol. 19, No. 2 (2021): 182-199 \\ Website: http://journal.iain-manado.ac.id/index.php/JIS ISSN 2528-0368 (online) ISSN 1693-4202 (print)}

The portion of the division in the third rule offered by Muhammad Syahrûr is very profitable for women. Here, not only applies the rule of $1: 1(50 \%-50 \%)$, but on one occasion, women can have the right to control the entire property (which is at the maximum threshold) if the heir only has one daughter (Syahrur).

After knowing the details regarding the division of inheritance with the hudûd theory of Muhammad Syahrûr. We can understand that Syahrûr tried to free the ummah from the entanglement of the classical ulama's understanding which was so rigid. On the reconstruction of Syahrûr through the theory of limits or limits, he tries to realize equality that is gender justice. For Syahrûr, what is meant by equality here is not individual equality (nadzrah al-fardiyah), but what God wants is the equality of men's groups (majmû'at al-dzukûr) and women's groups (majmû'at alinâts) (Syahrur).

The division of inheritance carried out by Syahrur leads to gender equality. Number 2 (66.6\% of total assets) is the maximum limit that Allah Swt. has set, and the minimum limit is number 1 (33.3\% of total assets). This division means it is wrong to give $70 \%$ of his wealth to men for various reasons, while the woman only gets 30\%, which comes out of Allah's decree (hudûdillah). With Muhammad Syahrûr's hudûd theory, one should be freed from the confinement of classic inheritance. As; 1) The problems of radd and ' $a w l ; 2)$ The problem of the superiority of men and women cannot be âjib; 3) The problem of fauqa itsnatayni (women above two); 4) The problem of $1 / 3$ bâq (leftover) and $1 / 2$ bâq (leftover) going to and to whom to give it (Syahrur).

\section{Sangkolan; The Division of Madurese Inheritance and Gender Bias}

Madura is the name of a small island to the north of East Java with an area of $\pm 5,168$ square kilometers, with a total population of almost 4,000,000 spread over four districts starting from the western tip of Bangkalan, Sampang, Pamekasan and at the eastern end is Sumenep district (Fath). One thing that has surfaced in the public eye is the carok incident; namely, a dispute between two parties based on defending rights (read Madura; téngka) using a sharp weapon called an arék or sickle. Following the motto "ango'an pote tolang katembéng pote matah." Meaning: better white bones (dead) than the whites of the eyes (to be ashamed) (Rochana).

Nevertheless, there is no doubt about understanding religion, as evidenced by the many Islamic boarding schools that have been established in Madura (Hipni and Karim). Wiyata (a researcher on Madura) stated that Islam is not just a way of life. Still, Islam has become a guide to life (identity and identity) for the Madurese community. As one proof of religious devotion and loyalty to others is the existence of settlements in groups facing each other (right-left) with a larger or kobhûng (wooden stilt building) at the west end as a center of worship which became known as the "tanean lanjhéng" (Sa'dan) settlement (Wiyata).

Even so, the socio-cultural of the Madurese community is thick with religious advice. This socio-cultural does not prevent Madura from running away 


\section{Jurnal Ilmiah Al-Syir'ah Vol. 19, No. 2 (2021): 182-199 \\ Website: http://journal.iain-manado.ac.id/index.php/JIS ISSN 2528-0368 (online) ISSN 1693-4202 (print)}

from its rich cultural identities, such as the bull race, the sapeh sono' contest (cow decoration), rokat and the distribution of inheritance, which still uses the Sangkolan custom. The term Sangkolan itself is an expression of inheritance given by the heir to the heirs, such as land, house buildings, and other valuable objects distributed without Islamic inheritance and cannot be traded (Hipni and Karim). The process of dividing the inheritance of the Madurese community has three phases: first, when the heir is still alive; second, after the testator dies; and third, carried out before and after the inheritor died (Maimun).

Based on the author's findings, inheritance among the Madurese is usually distributed when the heir lives. This finding is known as "hibbé" (in fiqh, it is a grant). The concept of grant in fiqh (syara') is the giving or transfer of ownership (voluntarily) solely because of worship using ijab-qabul not to respect someone, not because of hoping for a reward, and there are no reciprocal frills (Bakar). The grants are not only intended for families in a basic concept but for non-families are also justified. However, it is different from the Madurese, who have roots in the tradition that parental gifts in terms of inheritance are called hibbe (grants) to distinguish a regular grant from a Madurese-style grant; it is usually known as an "inheritance grant."

This is where the term "Sangkolan" appears. The process of giving is "hibbe" while the object is given island, house, and others called "Sangkolan." If the author makes it simple, Sangkolan is a term for objects given by parents or elders as an inheritance. Sometimes the term Sangkolan distinguishes between ancestral heritage objects or elders from objects of our labor.

Based on the author's search, the purpose of the property being given before the heir dies is to avoid disputes later because they feel that there is injustice. The heirs are collected (consultation, negotiation, and so on) occur so that the assets are distributed evenly. The distribution system also has three typologies, namely:

First, 1:1 even distribution, this division is given equally from parents to their children regardless of male or female. As an example, Ramna (person's name) has four children (three boys and one girl), all of whom are married, some are married to other relatives, some are non-family (the term Madura: oreng loar) with social status as all farmers. Each of the four children was given one plot of rice fields, and this distribution was evenly distributed between boys and girls (Bakar).

Second, women benefit. The next division of inheritance is vulnerable to women who benefit. Why is that?. This division is vulnerable to occur when girls are the youngest children. In practice, the youngest daughter will usually live with the parents who gave birth. The woman's part will be more because she has to take care of her parents and get a pathobin plug. The term patobin is a parent's house which is sometimes used as a gathering place for relatives (pamoléan) such as on holidays, birthdays, or other significant days (Hipni and Karim). This division is not patent for women, and it's just a general rule that happens usually girls are chosen to take care of their parents because girls are more patient daughter can go 
with her husband so that the brother who lives with the parents is the brother. Because in the life of the Madurese apply the rule "Mun Binik Nurok Mun Lakek Ngibeh." women usually go with their husbands, while men usually bring their wives to live with them. This is commonly known as the "matrilocal" marriage system.

The third, the Relative Division the author calls the relative division because sometimes men benefit and sometimes women benefit. They referred to the social factors of the beneficiaries' lives progress of the times, where the Madurese community began to be touched by the world of education so that many scholars with doctoral degrees emerged. Finally, they also hold many positions, either as State Civil Apparatus (ASN) or sitting at office desks with income that can be considered sufficient. Based on this socio-economic life that affects the inheritance distribution system.

For example, Suja'i (person's name) has three children (two boys and one girl). During his early childhood and adolescence, the child was sent to school until, in the end, one son had the good fortune as a civil servant in the police force, while his sister became a teacher for Civil Servants (PNS). However, the other brother was not destined to have a steady job, so he only helped his mother and father farm. When his parents died, the brothers who got more Sangkolan inheritance were the brothers who did not have established jobs. In contrast, the other brothers with qualified professions got less-considering the costs of the struggle of parents who have made their children successful and have jobs, getting less inheritance. Because sometimes they are willing to sell their fields to make their children successful with a decent life.

Based on the explanation above, the distribution of Sangkolan inheritance in the Madurese community contains a gender bias. Equality between men and women under the pretext of justice is not only 1:1, but it is also possible for girls to receive more or more benefits from men, such as when they get Sangkolan Patobin.

\section{The Relevance of Hudûd Syahrûr's Theory to the Inheritance of the Sangkolan of the Madurese Community}

After elaborating on the concept of inheritance distribution which has an impact on gender bias, both through conceptual studies of Muhammad Syahrûr's hudûd theory and empirical, theoretical studies on the distribution of ancestral inheritance in the Madurese community, the authors found several things as material for analysis related to the relevance of Muhammad Syahrûr's hudûd theory with inheritance distribution. The customs of the Madurese community; First, theoretically, Muhammad Syahrûr's legacy is quite different. This difference can be seen in terms of existing ijtihad reasoning. Inheritance in Muhammad Syahrûr's view still tends the Qur'an. The Madurese community is an ancestral inheritance that is formulated not based on the Qur'an but for the benefit of the family. 


\section{Jurnal Ilmiah Al-Syir'ah Vol. 19, No. 2 (2021): 182-199 \\ Website: http://journal.iain-manado.ac.id/index.php/JIS ISSN 2528-0368 (online) ISSN 1693-4202 (print)}

Second, in his concept, Syahrûr assumes that inheritance is also part of a will, so that a will is considered the highest priority. Third, fairness in Syahrûr's concept is mathematical (measured). In contrast, fairness in the concept of inheritance of the Madurese community is not mathematical, sometimes using social measures, sometimes by measuring the benefits of objects, etc. Fourth, the concept of justice built by Syahrûr is not based on individuals/individuals but on the concept of gender/gender justice between men and women. In the sense that Syahrûr takes into account the equality of the male group (majmû'at al-dzukûr) with the female group (majmû'at al-inâts). Whereas in the division of inheritance, the Madurese community considers individual justice (nadzrah al-fardiyah).

The author's focus in conducting this study lies in the systematic distribution of inheritance that contains gender justice. That is, systematically, the division of inheritance between Muhammad Syahrûr and the Sangkolan inheritance of the Madurese community has similarities or relevance in giving justice. At the same time, the differences occur in the problem of using arguments only. Even so, from the two inheritance concepts, both Muhammad Syahrûr and the traditional inheritance of the Madurese community both fought for gender justice, only one in the form of an individual and the other collectively between men and women.

As an example in the systematic distribution of inheritance between Muhammad Syahrûr and Madurese customary inheritance, it is to prioritize justice based on the responsibility or burden of each heir recipient. So that the portion in receiving inheritance moves statically not only 2:1 but sometimes 1:1 (shared equally), and there are times when women occupy the highest (maximum) limit by getting more benefits on property. Like if he (in Syahrûr's concept) gets a share of the Patobin Sangkolan when living together in caring for parents (in the Madurese inheritance concept).

The understanding between the verse as revelation and gender inheritance resulting from reason and culture is a form of maslahah. Madurese people certainly understand the text of inheritance in the Qur'an; it's just that sometimes they put forward mashlahah with the distribution of ancestral inheritance so that they leave disputes. The application of prioritizing mashlahah over texts.

\section{CONCLUSION}

Based on the study, the author concluded a relationship between inheritance distribution with the hudûd theory of Muhammad Syahrûr's method and the division of Madurese customary inheritance (hibbe inheritance) to realize gender equality individually collectively between beneficiary groups. It's just that the difference occurs in terms of istimbath al-hukm or the method of taking arguments. If Madura is based on local culture (URF), the inheritance used is customary. Meanwhile, Muhammad Syahrûr's hudûd theory refers to the text of al-Tanzîl al-Hakîm by reconstructing the interpretation. 


\section{ACKNOWLEDGMENTS}

The author expresses tremendous respect and gratitude to all parties, especially the academic community of the Madura State Islamic Institute, the teacher council, and in particular the parents who always take the time to pray for the smooth implementation of the author in conducting research.

\section{REFERENCES}

Al-Ahdâl, A. B. Y. I'ânah Al-Thâlib Fî Bidâyah Ilm Al-Farâid. Arab Saudi: N.p. Print.

Al-Hadhramî, S. B. S. 'Iddah Al-Fâridh Fî 'Ilm Mîrâts. Pasuruan: Pustaka Sidogiri. Print.

Al-Malībāri, Z. al-D. bin A. al-'Azîz. Fath Al-Mu 'în Bi Syarh Qurrah Al- 'Aîn Bi Muhimmat Al-Dîn. Gerbang Andalus. Print.

Al-Nawâwî, A. Z. M. Y. Al-Majmû' Syarh Al-Muhadzab. Vol. 6. Damaskus: Dâr al-Fikr. Print.

Al-Shâbûnî, M. A. Al-Tibyân Fî̀ "Ulûm Al-Qur"an. Jakarta: Dar al-Kutub alIslâmiyah, 2003. Print.

Al-Zuhailî, W. Al-Fiqh Al-Islâm Wa Adillatuh. Vol. 10. Damaskus: Dâr al-Fikr. Print.

Anis, I. Al-Mu 'jam Al-Wasìth. Vol. 1. Beirut: Dar al-Ilmiyah, 1987. Print.

Bakar, A. I'ânah Al-Thâlibîn. Vol. 3. Surabaya: al-Hidâyah. Print.

Fath, K. et all. Pamekasan Dalam Sejarah. Pamekasan: Pemerintah Kabupaten Pamekasan, 2006. Print.

Hipni, Muhammad, and Muh Karim. "Akar Budaya Emansipasi Pekerja Imigran Wanita Madura; Kajian Terhadap Praktik Waris Adat Madura." KABILAH: Journal of Social Community 4.2 (2019): 1-15. Print.

Ismail, Ahmad Syarqawi. Rekonstruksi Konsep Wahyu Muhammad Syahrur. Yogyakarta: eLSAQ Press, 2003. Print.

Khisni, H A. Hukum Waris Islam. Semarang: UNISSULA Press, 2017. Print.

Maimun, M. "The Existence of Mèkol Nyo'on Formula in Traditional of Inheritance Division in Madura." KARSA: Journal of Social and Islamic Culture 24.1 (2015): 67-83. Print.

Mâjah, Ibn. Sunan Ibn Mâjah. Vol. 2. Dâr Ihyâ' al-Kutub al-'Arabiyyah. Print.

Muamar, Afif. "Rekonstruksi Hukum Waris Islam (Telaah Pemikiran Muhammad Syahrur)." Mahkamah: Jurnal Kajian Hukum Islam 2.2 (2017): 205-215. Print.

Murtadlo, Muhammad Ali. "Keadilan Gender Dalam Hukum Pembagian Waris Islam Perspektif the Theory of Limit Muhammad Syahrur." Tafáqquh: Jurnal Penelitian Dan Kajian Keislaman 6.1 (2018): 76-89. Print.

Mustaqim, Abdul. "Teori Hudûd Muhammad Syahrur Dan Kontribusinya Dalam Penafsiran Al-Qur'an.” AL QUDS: Jurnal Studi Alquran dan Hadis 1.1 (2017): 1-26. Print.

Raco, J R. Metode Kualitatif(Jenis, Karakteristik, Dan Keunggulannya). Jakrta: PT Grasindo, 2010. Print.

Rafiq, A. Fiqih Mawaris. Jakarta: PT Raja Grafindo, 2002. Print.

Hacking Muhammad Syahrûr's Hudûd Theory And Its Relevance To The Inheritance Of Sangkolan Madurese People 
Rochana, Totok. “Orang Madura: Suatu Tinjauan Antropologis.” Humanus 11.1 (2012): 46-51. Print.

Saifuddin. "Muhammad Syahrur Dan Teori Limitnya." Empirisma: Jurnal Pemikiran dan Kebudayaan Islam 25.1 (2016): 73-81. Print.

Suryati. Hukum Waris Islam. Yogyakarta: Penerbit Andi, 2017. Print.

Syahrûr, M. Al-Kitâb Wa Al-Qur'ân; Qirâ'ah Mu'âshirah. Damaskus: al- Ahâli li al-Thab' wa al-Nasyr wa al-Tauzî', 1990. Print.

Syahrur, Muhammad. Metodologi Fiqih Islam Kontemporer. Trans. Sahiron Syamsuddin and Burhanudin. Yogyakarta: Kalimedia, 2015. Print.

Wahidah. Buku Ajar Fikh Waris. Banjarmasin: IAIN Antasari Press, 2014. Print.

Wiyata, A Latief. Mencari Madura. Jakarta: Bidik-Phronesis Publishing, 2013. Print.

Yudha, A. K. "Waris Kesetaraan Gender: Komparasi Perspektif Wahbah AlZuhaily Dan Muhammad Syahrur." Muwazah; Jurnal Kajian Gender 11.1 (2019): 1-24. Print. 